\title{
Parnopes grandior (Pallas, 1771) (Hymenoptera: Chrysididae) in Poland and its status in adjacent countries
}

\author{
Bogdan JAROSZEWICZ \\ Białowieża Geobotanical Station of Warsaw University, 19 Sportowa Street, 17-230 Białowieża, Poland; \\ e-mail: b.jaroszewicz@uw.edu.pl
}

\begin{abstract}
Parnopes grandior is believed to occur in Poland at northern limits of its range. However, it was not recorded in the country for over 50 years due to unknown reasons. In a number of Central and East European states the species is only recently found in single and isolated sites. Exclusively in Ukraine and Byelorussia it occurs in larger numbers and over bigger territories. In spite of this, it is not subject to legal protection in most of the countries, except in Slovakia and the Russian Federation. Rediscovery of the species in the vicinity of Białowieża Primeval Forest is the first record of its presence in Poland after 1955. This new situation might be the effect of the species' north-eastern expansion, characteristic of many invertebrates over the last $10-15$ years, due to a climate change.
\end{abstract}

Key words: Parnopes grandior, Chrysididae, Białowieża Primeval Forest, Jelonka Reserve, Central Europe, Eastern Europe

\section{INTRODUCTION}

Parnopes grandior (Pallas, 1771) is known in Southern, Central and Eastern Europe, Asian Turkey, the Caucasian republics (Georgia, Armenia, and Azerbaijan), Lebanon, Syria, Israel, Jordan, the Sinai Peninsula, the Arabian Peninsula, Iraq, Iran, and Northern Africa (Noyes 2004). Up to the 1950s, the species used to be numerous in some parts of Poland (Banaszak 2004, Noskiewicz \& Puławski 1958, Szulczewski 1917).

The ecology of the species is not well known. It parasitizes nests of digging wasps of the Bembix Fabr. genus (Noskiewicz \& Puławski 1958). In Poland the only host is Bembix rostrata (L.), nesting at dry, sandy and sunny habitats (Banaszak 2004). According to Linsenmaier (1997), the imagines of Parnopes grandior (Fig. 1) feed on flowers of Asteraceae, Alium sp., Thymus sp. and Armeria sp.

\section{MATERIAL AND METHODS}

Observations of $P$. grandior took place during a faunistic survey carried out in July 2005 near Białowieża Primeval Forest. One specimen was caught by net.

The number of $B$. rostrata individuals in the colonies where $P$. grandior were observed was estimated on the basis of the number of flying individuals in combination with the number of entrance holes to the nests.

Data about the distribution and conservation status of $P$. grandior in Central and Eastern Europe were gathered from both published materials and queries carried out among entomologists of the region. 


\section{RESULTS}

Four females of Parnopes grandior were registered in 2005 on three sites (Fig. 2) in the vicinity of Białowieża Primeval Forest, NW Poland (Fig. 3). One specimen was caught by net near Jelonka, a village.

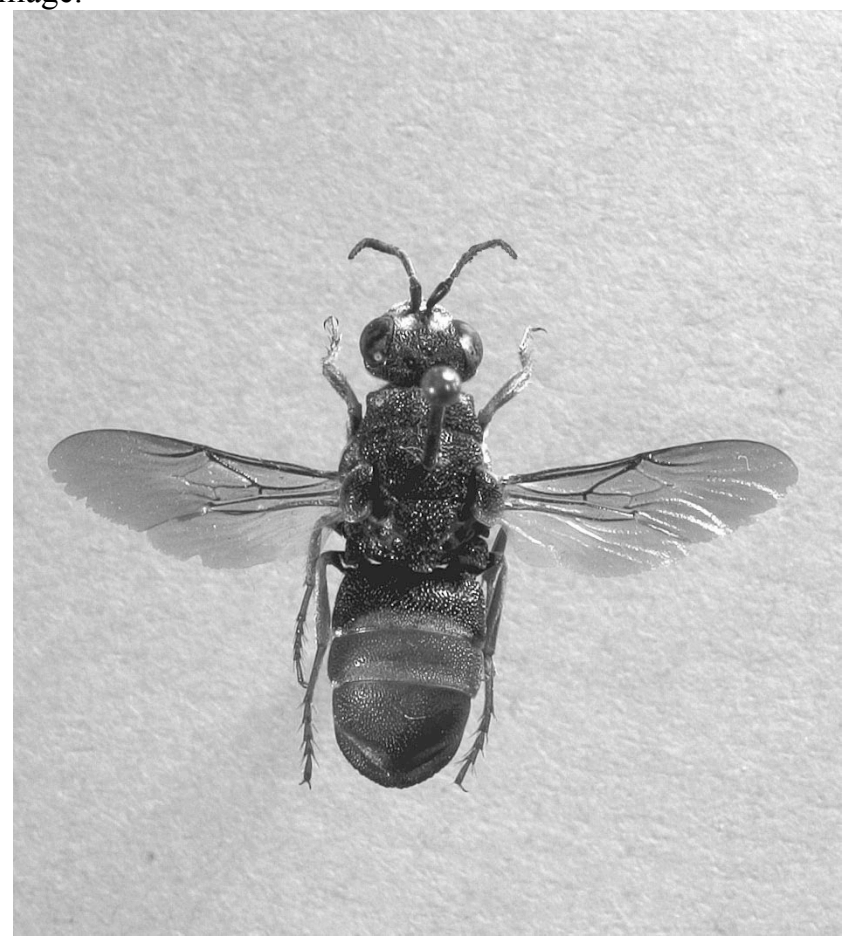

Fig. 1. Parnopes grandior, female. (Photo A. Bołbot).

Site A. Jelonka Reserve (UTM FD 63) covers a part (227 ha) of a poor Scots pine forest growing on fields abandoned after World War I. The forest burnt in the early 1990s. A strict protective regime applied there has allowed undisturbed post-fire regeneration of the forest. The reserve includes young-stage pine forest, with patches of open sandy grassland, juniper scrub and aspen-pine-juniper brush. Two females of $P$. grandior were observed in the $B$. rostrata colony established on a sandy road. The number of $B$. rostrata females in the colony was estimated at ca. 20 individuals, with nests distributed within 20-30 m. The site was very sunny and open, only to a limited extent overshadowed by young silver birches and Scots pines.

Site B. Vicinity of Grabowiec, a village (UTM FD 63). One female was seen on a sandy road crossing abandoned fields displaying an advanced process of spontaneous forest regeneration. The $P$. grandior was observed on a part of the sandy road with only a few scattered $B$. rostrata nests. Most of the area was covered with grasses and forbs growing between young trees of Scots pine and silver birch (ca. 5 years old).

Site C. A small forest complex by the road between Dubicze Cerkiewne, a village, and Hajnówka, a town (UTM FD 63). P. grandior (one female) was observed on the sandy road at the edge of the forest (Scots pine aged ca. 40 years) and an enclave of an extensively farmed field. The exposure of the forest edge was to the South-West. The colony of B. rostrata consisted of 10 nesting holes scattered on the road over a distance of ca. $100 \mathrm{~m}$. 
The results of the 2005 query about the species' status in Central and East European countries are presented in Table 1.

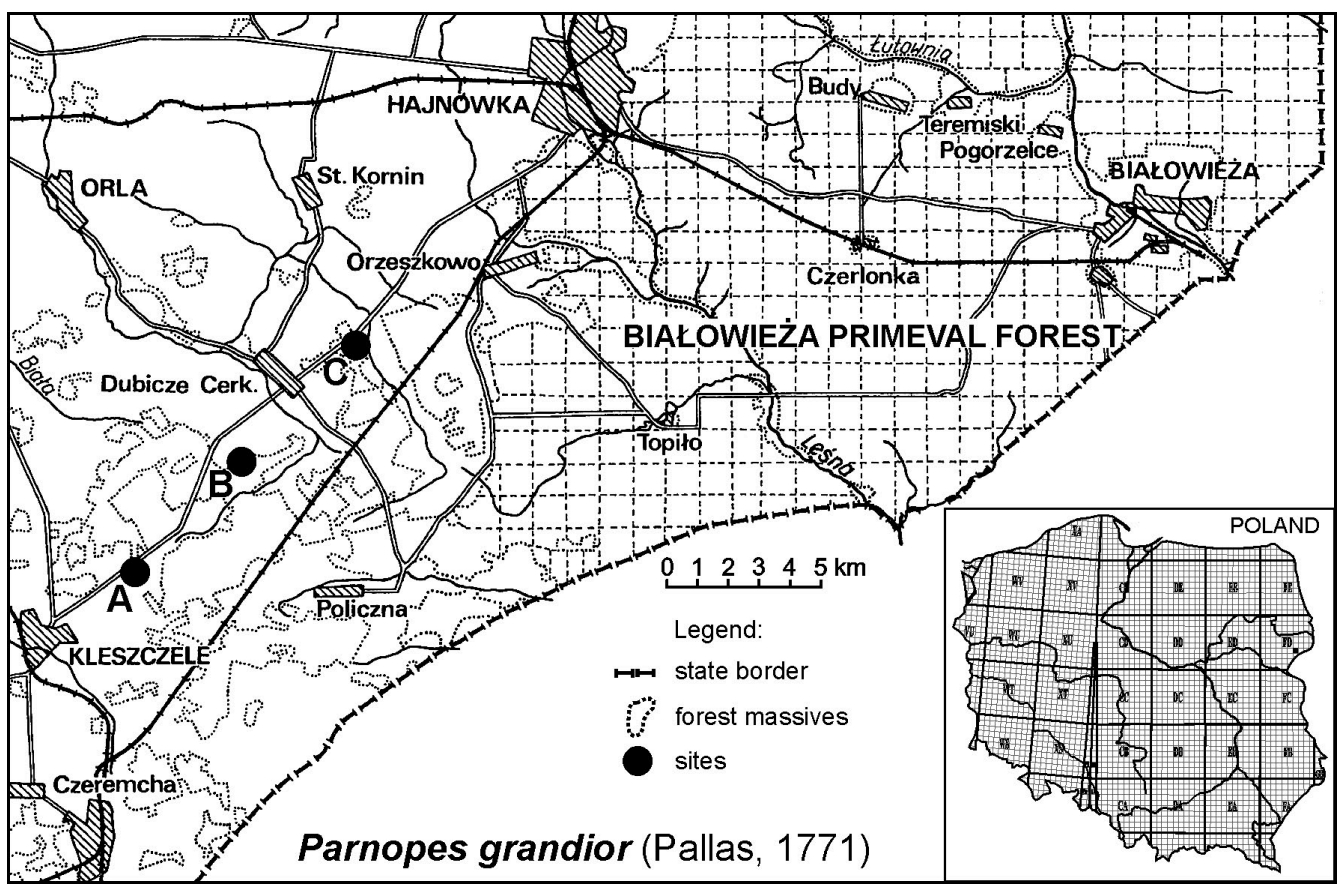

Fig. 2. Sites of Parnopes grandior discovered in 2005 in the vicinity of Białowieża Primeval Forest. Descriptions of sites (A, B, C) are in the text.

\section{DISCUSSION}

In most Central and East European countries the only occurring host of $P$. grandior is $B$. rostrata. It is still relatively numerous in sandy habitats. Up to the 1950 s both species used to be common throughout Central and Eastern Europe (Banaszak 2004, Tikhonov 2002, Niehuis 1998, Noskiewicz \& Puławski 1958, Balthasar 1954). Despite still existent relative abundance of its host, $P$. grandior was recorded in Poland for the last time in the years 1951-1955 on three sites on the Mazovian Upland (Banaszak 2004, Fig. 3). The decrease in number of $P$. grandior in Central and Eastern Europe, including the Russian SSR and Federation, began in the 1950s (Banaszak 2004, Mandery 2003, Tikhonov 2002, Noskiewicz \& Puławski 1958, Balthasar 1954). From then on, efforts to rediscover the species within Poland were not successful (Banaszak 2004). In other Central and East European countries, the latest half a century brought records merely once every few years, and usually only from single, isolated sites (Table 1) in spite of the fact that all these countries lie within the potential natural range limits of P. grandior (Noyes 2004, Linsenmaier 1997, Noskiewicz \& Puławski 1958). Only in Byelorussia and Ukraine has it been observed over wider territories lately (Drozdovskaya, pers. comm., Tsinkevich, pers. comm.). In other countries adjacent to Poland (the Czech Republic, Germany, Lithuania, and Slovakia), the last 10 years brought records of the species' presence on nothing more than single and isolated sites (Lukáš \& Tyrner 2000, Kraus 1998, Bogush, pers. comm., Budrys, in prep.), or else no data about the species at all (as in Kaliningrad District of the Russian Federation). 
The decrease in number of $P$. grandior is usually attributed to general changes in the soil and in land use (Banaszak 2004), especially to afforestation of sandy areas and paving of roads (Tikhonov 2002). Dry habitats are no longer used in farming or pasturing. Sandy areas become forests, the result of which is loss of habitats for the species in question. The aforementioned changes, however, cannot be used as the explanation for the species decline, because if so, they should also bring a decline in the population of the host species $-B$. rostrata, which in fact is still considered numerous in most Central and East European countries. In consequence, there must be some more, so far unknown factors responsible for the observed rapid decline in $P$. grandior over the last 50 years (change in soil characteristics, climate change, soil pollution). Any conclusions on that matter are very difficult, for the knowledge of the biology and ecology of the species is rather fragmentary and general (Woydak 2000, Linsenmaier 1997, Müller 1941).

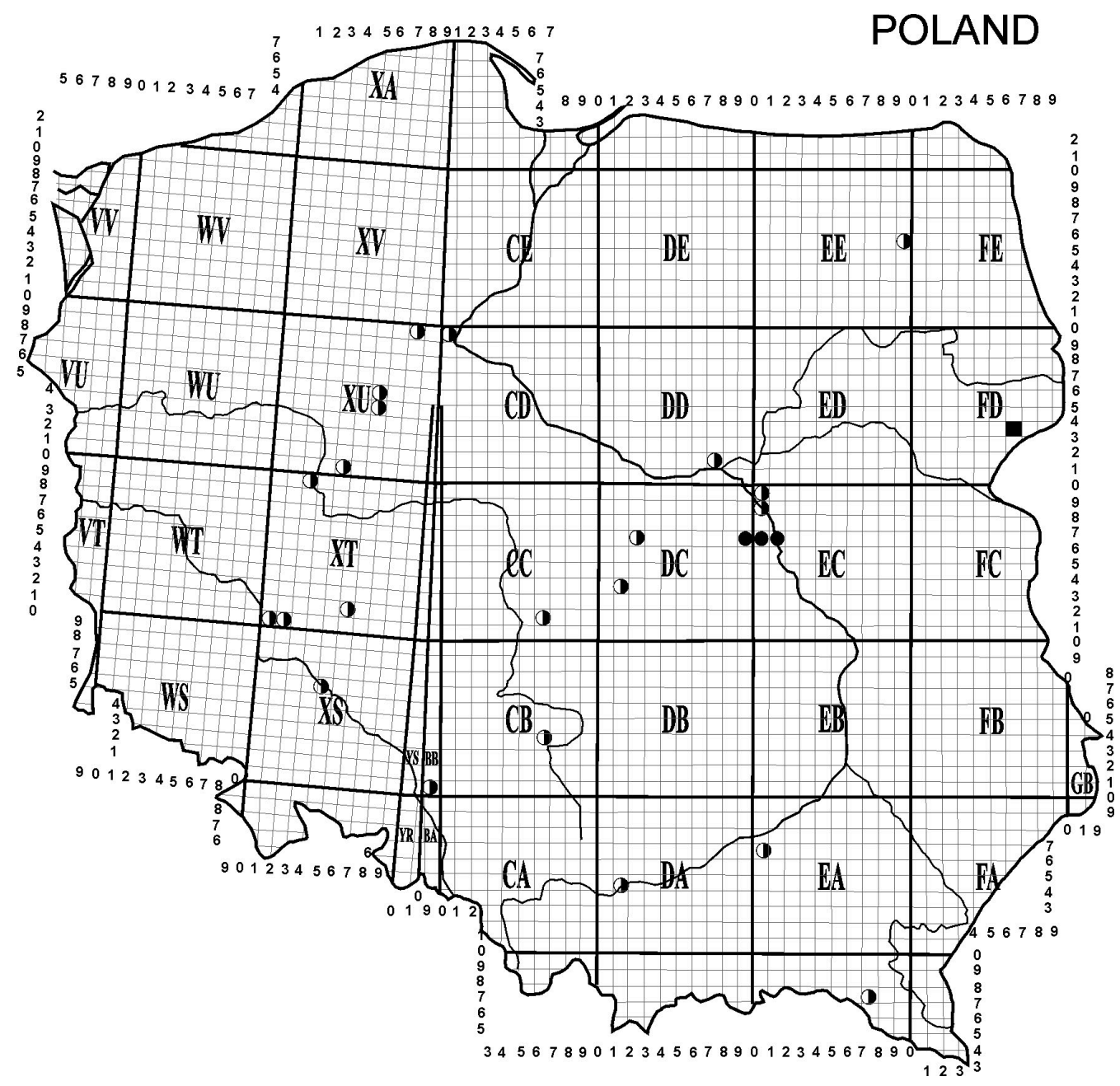

Fig. 3. Current (ם) and historical ( - in the1950s; - before 1950) distribution of P. grandior in Poland (after Banaszak 2004, updated). 
In Central and Eastern Europe P. grandior is protected by conservation acts only in Slovakia (Lukáš, pers. comm.) and the Russian Federation (Panfilov 2000). In other countries, it is either included in red lists or even totally absent in documents dealing with endangered or protected species (Table 1).

Table 1. Presence and conservation status of Parnopes grandior in Central and East European countries. CR critically endangered; DN - decreasing in numbers;

\begin{tabular}{|l|c|c|l|l|}
\hline Country & $\begin{array}{l}\text { Red } \\
\text { List }\end{array}$ & \multicolumn{1}{|c|}{$\begin{array}{c}\text { Legal } \\
\text { protection }\end{array}$} & \multicolumn{1}{|c|}{ Source } & \multicolumn{1}{|c|}{ Notices } \\
\hline Poland & CR & - & Banaszak 2004 & $\begin{array}{l}1955 \text { to 2005: species not recorded in any part of } \\
\text { Poland. }\end{array}$ \\
\hline Germany & CR & - & Niehuis 1998 & $\begin{array}{l}\text { Known recently in a few Landkreis in Bavaria } \\
\text { (Mandery 2003). }\end{array}$ \\
\hline Czech Rep. & - & - & $\begin{array}{l}\text { P. Bogush, pers. } \\
\text { comm. }\end{array}$ & $\begin{array}{l}\text { Occurs in south-eastern Moravia, around Hodonín and } \\
\text { Bzenec, critically endangered with extinction (P. } \\
\text { Bogush, pers. comm.) }\end{array}$ \\
\hline Slovakia & - & + & Lukáš 2001 & $\begin{array}{l}\text { Recorded twice during the last 10 years: in 1998 in } \\
\text { Devínská Kobyla NR (Lukás \& Tyrner 2000) and in } \\
\text { 2005 in the vicinity of Bratislava (J. Lukáś, pers. } \\
\text { comm.). }\end{array}$ \\
\hline Ukraine & - & - & $\begin{array}{l}\text { A. Drozdovskaya, } \\
\text { pers. comm. }\end{array}$ & $\begin{array}{l}\text { Species observed in southern districts of Ukraine. Not } \\
\text { included into Red book (A. Drozdovskaya, in prep.). }\end{array}$ \\
\hline Byelorussia & - & - & $\begin{array}{l}\text { V. Tsinkevich, pers. } \\
\text { comm. }\end{array}$ & $\begin{array}{l}\text { In 2001-2002 the species was observed in central and } \\
\text { southern parts of the country. Listed in Annex to Red } \\
\text { data book of Byelorussia as a species in need of special } \\
\text { attention and research (V. Tsinkevich, pers. comm.). }\end{array}$ \\
\hline $\begin{array}{l}\text { Russian } \\
\text { Federation }\end{array}$ & DN & + & $\begin{array}{l}\text { In 2005, a population of P. grandior was found in } \\
\text { Dieveniskes Regional Park, SE Lithuania (E. Budrys, } \\
\text { in prep.). }\end{array}$ \\
\hline
\end{tabular}

The Białowieża Primeval Forest is one of the best faunistically studied natural areas in Europe (Gutowski \& Jaroszewicz 2001, 2004) and hymenopterans have been subject to study there since 1915 (Bischoff 1925). It is therefore unlikely that such a distinctive species should be omitted. The rediscovery of $P$. grandior in the vicinity of the Białowieża Primeval Forest in Poland and a simultaneous discovery of a population in south-eastern Lithuania (E. Budrys, pers. comm.) may suggest some kind of repeated colonization or invasion to the North-East by the species. The process of poleward shift in geographical ranges due to a climate change is characteristic of many organisms (Parmesan et al. 2004). A northward migration of $P$. grandior is potentially possible, because the range of its host species extends much further to the North, in Sweden and Finland up to 62 degrees North (Lomholdt 19751976). However, to prove this hypothesis about the northward expansion of the species, further monitoring of populations and search for its presence in colonies of the host are needed.

\section{ACKNOWLEDGMENTS}

I would like to thank the following fellow entomologists from Central and Eastern European countries for their kind supply of unpublished data: Petr Bogush from the Czech Republic, Jozef Lukáš from the University of Komensky (Slovak Republic), Alina Drozdovskaya from Taras Shevchenko National University in Kyiv (Ukraine), Vadim Tsinkevich from Belarus and Eduardas Budrys from Vilnius University (Lithuania). 


\section{REFERENCES}

BALTHASAR V. 1954. Zlatìnky - Chrysidoidea. Fauna ČSR 3. ČSAV, Praha, 271 pp.

BANASZAK J. 2004. Parnopes grandior (Pallas, 1771) Sawczynka piaskowa. In: GŁowACiŃSKi Z. \& NowACKI J. (eds), Polska czerwona księga zwierząt. Bezkręgowce. (Invertebrates.), pp: 174-175. Institute of Nature Conservation PAS \& The A. Cieszkowski Agricultural University, Poznań-Kraków, 445 pp.

BISCHOFF H. 1925. Hymenoptera (Aculeata, Ichneumonidae, Chalastogastra). In: STECHOW E (ed.), Beiträge zur Natur und Kulturgeschichte Lithauens und angranzender Gebiete, pp. 278-334. Abhandlungen Bayerische Akademie der Wisseenschaften, München, Suppl. 6-9, 148 pp.

Gutowski J. M. \& JARoszewiCZ B. 2004. Puszcza Białowieska jako ostoja europejskiej fauny owadów. Wiadomosci entomologiczne 23 (Suppl. 2): 67-87.

Gutowski J. M. \& JARoszewicz B. (eds) 2001. Catalogue of the fauna of Białowieża Primeval Forest. Instytut Badawczy Leśnictwa, Warszawa, 403 pp.

ILIASHENKO V. YU. \& ILIASHENKO E. I. 2000. Krasnaya kniga Rossii: pravovye akty [Red Data Book of Russia: legislative acts]. State committee of the Russian Federation for Environmental Protection, Moscow., 143 pp. (In Russian)

KRAUS M. 1998. Die frühere und heutige Verbreitung der Dolchwespe Scolia sexmaculata (Müller, 1766) und der Goldwespe Parnopes grandior (Pallas, 1771), zweier Bewohner von Binnendünen und Flugsandfeldern in Bayern (Hymenoptera). Galathea (Nürnberg) 14: 111-128.

LINSENMAIER W. 1997. Die goldwespen der Schweiz. Veröffentlichungen aus dem Natur-Museum Luzern 9: 1-139.

LomHold O. 1975-1976. The Sphecidae (Hymenoptera) of Fennoscandia and Denmark. Fauna Entomologica Scandinavica (Klampenbork) 4: 1-2, 1-452.

LUKÁŠ J. 2001. Červený (ekosozologický) zoznam blanokrídlovcov (Hymenoptera) Slovenska. In: BALÁž D., MARHOLD K. \& URBAN P. (eds), Červený zoznam rastlín a živočíchov Slovenska, pp.129-133. Státna ochrana prírody Slovenskej republiky, Banskà Bystrica, 160 pp. Ochrona. Prírody 20 (Suppl.).

LUKÁŠ J. \& TYRNER P. 2000. Zlatìnky (Hymenoptera: Chrysididae) Státní př́rodní rezervace Devínská Kobyla. Klapalekiana 36: 113-123.

MANDERY K. 2003. Arbeitsatlas der Bienen und Wespen Bayerns. http://www.buw-bayern.de

MüLler M. 1941. Bembix rostrata und Parnopes grandior Pall. (Hym.). Mitteilungen der Deutsche Entomologischen Gesellschaft 10: 4-7.

NiEHUIS O. (ed.) 1998. Rote liste der Goldwespen (Hymenoptera: Chrysididae). In: BinOt M., Bless R., Boye P., GrutTKe H. \& PRETSCheR P. (eds), Rote liste gefährdeter Tiere Deutschlands, pp. 134-137. Bundesamt für Naturschutz, Bonn-Bad Godesberg, 434 pp.

Noskiewicz J. \& PuŁAWSKi W. 1958. Klucze do oznaczania owadów Polski. Błonkówki - Hymenoptera. 24 (55-56). Złotolitki - Chrysididae. PWN, Warszawa, 65 pp.

NOYES J. 2004. Fauna Europaea: Hymenoptera, Apocrita excl. Ichneumonoidea. Fauna Europaea version 1.1, http://www.faunaeur.org

Panfilov D. V. 2000. Parnopes krupnyjj. Parnopes grandior. In: Danilov-Danilyan V. I. (ed), Krasnaya kniga Rossiji. Astrel, Moscow, 872 pp. (In Russian)

Parmesan C., Gaines S., Gonzales L., Kaufman D. M., Kingsolver J., Peterson A. T. \& Sagarin R. 2004. Empirical perspectives on species borders: from traditional biogeography to global change. Oikos 108: 58-75.

SzUlCZEWSKI J. W. 1917. Beitrag zur Chrysididenfauna der Provinz Posen. Zeitschrift der Naturwissenschaftlichen Abteilung, Posen, 24: 29-35.

Tikhonov A. V. (ed.) 2002. Krasnaya kniga Rossii: Zhivotnye i rasteniya. M. Rosmen, Moskva, 414 pp. (In Russian)

WoydaK H. 2000. Die Goldwespe Parnopes grandior Pallas, 1771 und ihr Wirt, die Grabwespe (Kreiselwespe) Bembix rostrata (Linnaeus, 1758) (Hymenopera, Chrysididae et Sphecidae). Mitteilungen der Arbeitsgemeinschaft Ostwestfälisch-lippischer Entomologen 16: 42-48.

\section{STRESZCZENIE}

\section{[Parnopes grandior (Pallas, 1771) (Hymenoptera: Chrysididae) w Polsce i jego status w sąsiednich krajach]}

Sawczynka piaskowa (Parnopes grandior) do lat 50-tych XX wieku była uważana w Polsce za gatunek szeroko rozpowszechniony. Ostatni raz była notowana na terenie kraju w latach 1951-1955 na Mazowszu. W Europie Centralnej i Wschodniej sawczynka pasożytuje w gniazdach wardzanki (Bembix rostrata), gatunku wciąż stosunkowo licznego na piaszczystych siedliskach. W ciągu ostatnich kilkudziesięciu lat spadek liczebności sawczynki stwierdzono w większości krajów Europy Centralnej i Wschodniej. Wyjątek stanowią Białoruś i Ukraina, gdzie gatunek ten wciąż jest obserwowany na licznych stanowiskach. Przyczyny nagłego zniknięcia sawczynki w ciągu ostatniego półwiecza są trudne do wyjaśnienia, gdyż zmiany 
siedlisk powinny pociągnąć za sobą również spadek liczebności i zanik populacji $B$. rostrata, co nie miało miejsca. Odkrycie w 2005 roku nowych stanowisk Parnopes grandior w Polsce na przedpolu Puszczy Białowieskiej oraz na Litwie w Parku Regionalnym Devieniskes (Litwa) może sugerować ekspansję gatunku w kierunku północno-wschodnim. Mimo bardzo nielicznego występowania gatunku w większości krajów Europy Środkowej i Wschodniej nie jest on objęty żadną formą ochrony przyrody. Wyjątek stanowią Federacja Rosyjska i Słowacja, gdzie sawczynka piaskowa podlega ochronie gatunkowej. 